\title{
Learning and Teaching Support Materials for Training Philology Students in Ukrainian Universities from 1850 to 1917
}

\author{
Kan Olena \\ ORCID https://orcid.org/0000-0002-3975-5385 \\ Postgraduate student \\ Prof. Ye. Petukhov Department of Pedagogy, Psychology and Educational \\ Management, Kherson State University (Ukraine, Kherson)
}

\begin{abstract}
The article deals with learning and teaching support materials for training philology students in Ukrainian universities from 1850 to 1917. The author researches main learning and teaching support materials such as syllabus, curriculums, exams requirements, lecture notes, textbooks and guides etc. It is noted that at that period each university created its kit of learning and teaching support material which must be approved by the faculty council. Due to the lack of unified learning and teaching support materials, professors and university lecturers had to prepare their syllabus, curriculums, lectures notes as well as to select the textbook and guides. This reason caused the different level of competence while training philology students as it was completely dependable on the academic staff qualification. The author makes a conclusion that the lack of unified learning and teaching support materials can have as the negative as the positive impact on training philology students in Ukrainian universities. On the one hand, the level of competence mostly depended on academic stuff qualification but, on the other hand, it gave some freedom in the selection of materials that can provide some better results in training philology students.

Key words: learning and teaching support materials, syllabus, curriculums, lecture notes, exam requirements, Ukrainian universities, training philology students.
\end{abstract}

Актуальність дослідження. Питання підготовки майбутніх філологів $є$ актуальним на сучасному етапі розвитку системи освіти України. Методи, форми, прийоми навчання постійно модифікуються і знаходяться в центрі уваги багатьох дослідників, науковців, методистів. Удосконалення системи підготовки студентів філологічного профілю неможливо без вивчення історико-педагогічного досвіду.

Українські та закордонні вчені неодноразово зверталися до вивчення питання щодо підготовки філологів в системі вищої освіти. Проте, їх роботи мають або ознайомлювальний характер, або висвітлюють лише деякі аспекти підготовки філологів, або розглядають окремі дисципліни, які є невід'ємною частиною підготовки фахівців. У попередніх статтях ми дослідили історіографію підготовки майбутніх філологів, відображення проблем підготовки філологів на шпальтах періодичних видань та дисертаційних дослідженнях. У статті «Історіографія підготовки майбутніх філологів в університетах України в II половини XIX - початку XX століття» виділено три 
історіографічні періоди: 1) роботи, опубліковані в період, що досліджуєть (1850-1917 pp.), 2) наукові праці радянського періоду (1918-1990рр.), 3) дослідження на сучасному етапі (1991 - до теперішнього часу) [3, с. 49]. В межах нашої статті особливий інтерес становить перший період.

До робіт першого періоду відносяться в основному публікації, зроблені професорами навчальних закладів, науковцями, громадськими діячами, які опікувалися проблемами освіти, формами, змістом і методами навчання, які переважали в університетах того часу. Ще одним істотним джерелом інформації є огляди викладання по університетам, в яких містяться відомості про організацію навчання, форми, методи, навчально-методичне забезпечення підготовки майбутніх філологів, Всі так звані «класичні університети» мали подібні огляди, які видавалися щорічно. Ці видання містять інформацію щодо професорсько-викладацького складу, кількості предметів і годин на тиждень, стислий зміст курсів, перелік підручників та посібників тощо. Завдяки цим оглядам можна скласти досить цілісну картину щодо організації навчання, форм, методів, навчально-методичного забезпечення підготовки майбутніх філологів, які застосовувалися на історико-філологічних (університет Св. Володимира в Києві, Новоросійський в Одесі і Харківський університети) i філософських (Львівський i Чернівецький університети) факультетах.

«Історія Львівського університету» Л. Фінкеля [19] містить інформацію про всі факультети університету, включаючи філософський факультет, де здійснювалася підготовка майбутніх філологів.

Джерелами матеріалу з підготовки філологів у Чернівецькому університеті можуть служити історичні роботи, в яких оглядається розвиток $\mathrm{i}$ діяльність Чернівецького університету в цілому: «Чернівецький університет за 25 років його існування» $\mathrm{i}$ «Альма Матер Франциска Йосефа» А. Норста [20].

У досліджуваний період видавалися також підручники, посібники, конспекти лекцій для студентів, де міститься інформацію, що стосується викладання окремих предметів: зміст курсів, методику роботи з матеріалом, додаткову літературу для ознайомлення з темою, рекомендації для самостійної роботи студентів, а саме: «Поради студентам щодо читання древніх класичних авторів» В. Данилевича [1], «Лекції 3 
слов'янського мовознавства» Т. Флоринського [18], «Нарис грецьких старожитностей» В. Латишева [6], «Посібник до читання Гомера» I. Срізневського [16] тощо.

Проаналізувавши історико-педагогічні роботи, можна зробити висновок, що нині не існує комплексних і всебічних досліджень, які в повній мірі висвітлюють організацію навчання, форми, методи, навчально-методичне забезпечення підготовки майбутніх філологів в університетах України в 1850-1917 pp., тому дане дослідження $\epsilon$ актуальним. Деякі результати дослідження можуть бути використанні для подальшого вдосконалення підготовки філологів на сучасному етапі.

Виклад основного матеріалу. У II половині XIX - початку XX століття система освіти України перебувала в стані трансформації та розвитку. Університети намагалися впроваджувати нові методи і форми навчання, використовуючи свої власні і зарубіжні моделі.

В усіх університетах основна увага при підготовці філологів приділялася саме класичній філології та вивченню стародавніх мов та літератур. Також існували відділення або окремі кафедри російсько-слов'янської філології, а пізніше й романогерманських мов, хоча викладання так званих новітніх мов у різних варіаціях було присутнє в процесі підготовки майбутніх філологів в усіх університетах [8, с. 9].

В жодному університеті України того часу не було єдиного навчальнометодичного забезпечення. Кожен університет розробляв свої власні навчальні плани, робочі програми та вимоги для складання екзаменів. Так, наприклад, в «Таблицях розподілу навчальних предметів та часу викладання» [17] Харківського імператорського університету було узагальнено кількість годин на кожному факультеті та надавався перелік предметів, які вивчалися на кожному курсі історико-філологічного та інших факультетів. Таблиця містила інформацію щодо назв начальних дисциплін та кількості годин на тиждень на кожне півріччя навчального року кожного курсу.

Вимоги до складання екзаменів містилися в «Програмах напівкурсового випробування студентів» [13]. Програми складалися з трьох частин, а саме: правила щодо заліку за півріччя та напівкурсових випробуваннях, навчальні предмети напівкурсового випробування, програми 3 навчальних дисциплін історикофілологічного факультету. Напівкурсові випробування проводилися за програмою, яка затверджувалася Міністерством Просвіти. Так, наприклад, в Імператорському 
Харківському університету в 1891 році напівкурсові екзамени складалися після 2 та 4 семестрів з наступних дисциплін: класична філологія, староцерковно-слав'янська мова, грецька та римська історія, історія стародавньої філософії, російська історія, логіка, психологія, історія російської мови.

Брак єдиного навчально-методичного забезпечення на державному рівні призводив до того, що кожен професор готував свої власні конспекти та контрольні питання або самостійно обирав підручник (посібник) для занять зі студентами. Тобто рівень викладання цілком залежав від професійних якостей викладача, його обізнаності та якості підготовки з певного предмету. Підручники та посібники були, переважно, видрукувані іншою мовою - німецькою або латиною. Щоб користуватися такими джерелами, студенти мали знати ці мови на досить високому рівні [2, с. 184-185]. Це також спричиняло нестачу підручників, посібників та іншого навчального матеріалу для підготовки фахівців-філологів в університетах України в 1850-1917 pp.

Згідно з інструкціями Міністерства просвіти, викладачі мали надати на розгляд програму своєї дисципліни. Програм обов’язково мала містити пояснювальну записку та перелік рекомендованої літератури. Програма мала бути схвалена радою факультету. Лекції та посібники, які були підготовлені викладачами, також мали отримати позитивний висновок від ради факультету. Усе навчально-методичне забезпечення проходило процес цензури, під час якої вилучалися матеріали антидержавної спрямованості [7, с. 172-173].

Слід зауважити, що вибір форм і прийомів роботи на практичних занять безпосередньо залежав від курсу, що вивчається та навчально-методичного забезпечення, яке вибирається кожним викладачем самостійно - єдиних норм і правил не існувало. Так, наприклад, один із посібників, який використовувався при викладанні дисциплін «Грецька література та старожитності», «Римська література та старожитності» рекомендує студентам виконати низку завдань, яка істотно полегшує засвоєння матеріалу: ознайомитися 3 переліком посібників, які рекомендовані для читання одного із стародавніх авторів, ретельно проаналізувати коментарі до твору, які видавалися окремим виданням, вивчити інформацію про життя і діяльність автора , а також його критичні погляди й переконання. Для повного розуміння прочитаного тексту студент також має розібрати всі незрозумілі йому граматичні моменти, а також 
повністю розуміти переклад твору. Після такої ретельного опрацювання студент повинен оволодіти наступними знаннями, вміннями i навичками: 1) володіти інформацією щодо особи і літературного значення автора; 2) прочитати і перекласти будь-який, обраний викладачем, фрагмент 3 стародавнього тексту; 3) розуміти граматичні конструкції, речення і логічну послідовність думок; 4) вміти пояснити будьякі події твору або розповісти про діючу особу твору; 5) аналізувати твір [5, с. 132-133].

Проаналізувавши архівні документи, можна також знайти інформацію щодо викладання іноземних мов та її навчально-методичного забезпечення. Так, наприклад, у програмі 3 англійської мови за 1852-1853 навчальний рік, яка розроблена Д. Сіпневським та затверджена деканом i ректором Імператорського університету Св. Володимира стверджується, що викладачем у якості основного навчального забезпечення обрано підручник Робертсона. Цей підручник складено таким чином, що студенти можуть швидко і легко опанувати мову. Окрім цього, згаданий підручник був загальновживаним при викладанні англійської мови, як в університетах Російської Імперії, так і закордоном. Підручник Робертсона охоплював 20 тем чи лекцій. Перша частина $\epsilon$ теоретичною та містить граматичні правила англійської мови, які дають студентам навички читання, письма та говоріння. Опрацьовувати теоретичний матеріал рекомендовано наступним чином:

1) читання матеріалу;

2) переклад з англійської на російську чи французьку мови;

3) аналіз слів, їх етимологію та правопис;

4) опитування щодо граматики.

Друга частина є практичною, яка розвиває навички говоріння та перекладу, поповнює лексичний запас. Опрацьовувати практичний матеріал рекомендовано наступним чином:

1) стислий переклад теми з англійської на французьку;

2) бесіда з використанням вивчених слів;

3) вивчення та активізація активної лексики за темою;

4) написання твору чи виконання перекладу коротка робота чи переклад з російської на англійську мову на основі вивченої лексики [12, с. 13]. 
Власні доробки викладачів слугували підручниками для викладання курсів в університетах. Так, наприклад, очільник кафедри «Порівняльної філології слов'янських мов, літератур і мистецтва» Львівського університету А. Каліна видав підручник 3 історії польської мови «Formy gramatyczne јкzyka polskiego do kocca XVIII wieku. Lwyw» (1883 р.), який містив матеріали щодо граматичних форм польської мови кінця XVIII століття. Також його праці містять видання, що стосуються історії мов та інших галузей слов'янської філології: «O lieczebnikach w jzyku staropolskim, jako przycznek do historyji jzyka polskiego», «Ueber die Schreibung der Nasalvocale in den altpolnischen Denkmlern», «Studyja nad historyj jzyka buigarskiego» та інші, які використовувалися ним під час викладання та читання лекцій на філософському факультеті Львівського університету [4, с. 280-285].

Іншими прикладами начальної літератури можуть слугувати власно складені викладачами підручники, посібники, конспекти лекцій, як-от: «Поради студентам відносно читання стародавніх класичних авторів» В. Данилевича (1889 р.), «Посібник до читання Гомера» I. Срезневського (1875р.), «Огляд слов’янських літератур» В. Григоровича (1880р.), «Лекції з слов'янського мовознавства» Т. Флоринського (1895р.), «Нарис грецьких старожитностей» В. Латишева (1888 р.), В.І. Шерцель «Санскритська граматика» (1873) тощо.

Висновки. На підставі викладеного вище, можна зробити висновок про те, що в жодному університеті України того часу не було єдиного навчально-методичного забезпечення. Кожен університет розробляв свої власні навчальні плани, робочі програми та вимоги для складання екзаменів. Програми схвалювалися Міністерством просвіти та радою факультету. Підручники та посібники обиралися викладачем, переважно іноземними мовами, що вимагало досить високого рівня володіння мовою від студентів. В університетах України в 1850-1917 pp. брак єдиних навчальних планів і програм, навчально-методичного забезпечення унеможливлював контроль якості знань студентів та спричиняв нестачу навчально-методичного забезпечення підготовки фахівців-філологів. Проте, відсутність єдиних навчальних планів, програм, на нашу думку, можна віднести не лише до негативних, а й до позитивних характеристик навчального процесу, оскільки це надавало викладачам певну свободу дій, спонукало до 
творчості. Якщо педагог був фахівцем своєї справи, мав значний доробок з викладання мов, він міг ефективно використовувати ті чи інші методи та прийоми викладання.

\section{References}

1. Danylevych V. Sovety studentam otnositelno chteniya drevnikh klassicheskikh avtorov [How to read ancient authors: guidelines for students]. Sankt-Peterburg: Typ. V. S Balasheva, 1889. $36 \mathrm{p}$.

2. Yzvestiya o deyatelnosti $i$ sostoyanii nashykh uchebnykh zavedeniy [The bulletin about the operation and conditions of our educational institutions] // Zhurnal Ministerstva narodnogo prosveshcheniya. 1871. No. 2. P. 184-185.

3. Kan O. Iu. Istoriografiya podgotovki budushchikh filologov $v$ universitetakh Ukrainy vo II polovine XIX - nachale XX veka [The historiography of training philology students in Ukrainian universities in the second half of XIX - the beginning of the XX century]. Doklady Kazakhskoi akademii obrazovaniya / redkol. A.K. Kusaiynov (glava) i dr. Astana, 2018. No. 5. P. 48-56.

4. Kan O. Iu. Orhanizatsiia filolohichnoi osvity na filosofskomu fakulteti Lvivskoho universytetu imeni Yana Kazymyra u 1850-1917 rokakh [The organisation of philological education in the philosophical department of Jan Kazimierz Lviv University in 1850-1917]. Pedahohichnyi almanakh : zbirnyk naukovykh prats Kherson : KVNZ «Khersonska akademiia neperervnoi osvity», 2017. Vol. 33.P. 280-285.

5. Kan O. Iu. Formy, metody i priyemy obucheniya filologycheskikh distsyplin $v$ universitetakh Ukrainy vo II polovine XIX - nachala XX veka [Forms, methods and techniques of philological courses teaching in Ukrainian universities in the second half of XIX - the beginning of the XX century]. Sovremennyye problemy gumanytarnykh i sotsyalnykh nauk: materialy mezhdunarodnoi nauchno-prakticheskoy konferentsii / pod obshchey redaktsyiey A.K. Kusaynova (7 dekabrya 2018 goda, g. Astana). Astana: Yevraziskiy gumanytarnyy institut, 2018. P. 130-133.

6. Latyshev V. Ocherk grecheskikh drevnostey. Posobiye dlya gimnazistov starshikh klassov $i$ dlya nachinayushchikh filologov [The outline of Greek ancient studies. The guide for grammar school students and newcomer philology students]. Izdaniye 2-e pererab. $\mathrm{S}$.-Pb. : Tip. V. Bezobrazova i Komp., 1888. 355 p.

7. Levytska N. Naukovo-metodychne zabezpechennia vishchoii humanitarnoii osvity Naddniprianshchyny: druga polovyna XIX - pochatok XX stolittia [The scientific and methodological support for higher humanitarian education in Naddniprianshchyna: the second half of XIX - the beginning of XX century]. Ukraiinoznavstvo. 2012. No. 3. P. 171-176.

8. Obshchiy ustav Imperatorskikh Rossiyskikh Universitetov (18 iyunya 1863) [General statute of Imperial Russian universities (June 18 1863)] // Sbornik postanovleniy po Ministerstvu Narodnogo Prosveshcheniya. SPb, 1855-1864. T. 3. S.1040-1106.

9. Obshchiy Ustav imperatorskikh rossiyskikh universitetov 1884 goda [General statute of Imperial Russian universities of 1884]. Kharkov, 1911. 59 p. 
10. Pet'ko L.V. Inshomovna osvita u konteksti formuvannja novogo vchytelja v umovah universytets'koi' pidgotovky [University foreign language education in the context of the formation of a new teacher]. Pedagogika vyshhoi' ta seredn'oi' shkoly: [zb.nauk.prac'] ; za red. Z.P.Bakum. - Kryvoriz'kyj pedagogichnyj instytut DVNZ «Kryvoriz'kyj nacional'nyj universytet». Vol. 39. Kryvyj Rig : Drukarnja Romana Kozlova, 2013. P. 232-237.

11. Pet'ko L.V. Osvitnye seredovyshhe universytetu ta inshomovna pidgotovka studentiv [Educational environment of university and foreign language training of students] // Modernizaciya osvitn ogo seredovyshha: problemy ta perspektyvy : Materialy Chetvertoyi Mizhnarodnoyi naukovo-praktychnoyi konferenciyi (m. Uman, 11-12 zhovtnya 2018 r.) / gol. red. Osadchenko I. I. Uman`: VPCz «Vizavi», 2018. 184 p. P. 117-120.

12. Programma po angliyskomu yazyku za 1852-1853 uchebnyy god. Derzhavniy arkhiv m. Kieva (DAK) [The English language curriculum in 1852-1853 academic year]. F. 16. op. 465. spr. 96.53 ark.

13. Programmy polukursovogo ispytaniya studentov istoriko-filologicheskogo fakulteta $v$ Imperatorskom Kharkovskom universitete [Term examinations curriculum for students of historical-philological faculty in Imperial Kharkov University]. Kharkov: Universitetskaya tipografiya, $1891.38 \mathrm{p}$.

14. Sliusarenko N.V., Kokhanovska O.V. Transformatsiia vyshchoi zhinochoi osvity v Ukraini (XIX - pochatok XXI stolittia) [The transformation of higher female educationin Ukraine (XIX - the beginning of the XXI century)]. Visnyk Cherkaskoho universytetu (Seriia Pedahohichni nauky). 2018. Vol. 2. P. 124-130.

15. Sliusarenko N.V. Formy $i$ metody vyhovnoii roboty u vyshchomu navchalnomu zakladi [Forms and methods of extracurricular activites in a higher educational institution]. Tavriiskyi visnyk osvity. 2009. №3 (27). C. 107-116.

16. Sreznevskiy I.I. Posobiye $k$ chteniyu Gomera. Vypusk I. Etimologiya Gomerovskogo dialekta i kommentarii na 1-yu pesn Odissei [The guide to Homer. Issue 1. The etymology of the dialect and comments to the $1^{\text {st }}$ book of Odyssey]. SPb $1875.80 \mathrm{p}$.

17. Tablitsa raspredeleniya uchebnykh predmetov $i$ vremeni prepodavaniya $v$ Imperatorskom Kharkovskom universitete na 1850/51 uchebnyy god [The table of courses and credits in Imperial Kharkov University in 1850/51 academic year]. Kharkov, 1850. 11 p.

18. Florinskiy T. Lektsii po slavyanskomu yazykoznaniyu [Lectures on Slavic linguistics]. Kyiv : Universitet svyatogo Vladimira. 1897. 703 p.

19. Finkel L., Starzycski S. Historya uniwersytetu Lwowskiego [The history of Lviv University]. Lwyw: Drukarnia E. Winiarza, 1894. 351 p.

20. Norst A. Alma Mater Francisco-Josephina, Festschrift zu deren 25-jährigem Bestande. 1900. 146 p.

Translation of title, name of author, abstract and the list of references to the original language

УДК 378.091.2(477)(09)"1850/1917”(043.3) 


\section{Кан Олена. Навчально-методичне забезпечення підготовки філологів в університетах України в 1850-1917 рр.}

Стаття розглядає навчально-методичне забезпечення підготовки філологів в університетах України в 1850-1917 рр. Досліджуються основні навчально-методичні матеріали, такі як навчальні плани, програми, вимоги до іспитів, конспекти лекцій, підручники та посібники тощо. Визначається, що в цей період кожен університет створив свій набір навчальних матеріалів, які повинні бути затверджені радою факультету. Через відсутність уніфікованих навчальних та навчальних матеріалів, професорам та викладачам університету довелося готувати власні програми, конспекти лекцій, а також підбирати підручник та посібники. Автор робить висновок, що відсутність уніфікованого навчально-методичного забезпечення може мати як негативний, так і позитивний вплив на підготовку студентів філології в українських університетах.

Ключові слова: навчально-методичне забезпечення, навчальні плани, навчальні програми, конспекти лекцій, вимоги до іспитів, університети України, студентифілологи.

\section{Лimepamypa}

1. Данилевич В. Советы студентам относительно чтения древних классических авторов. Санкт-Петербург: Тип. В. С Балашѐва, 1889. 36 с.

2. Известия о деятельности и состоянии наших учебных заведений // Журнал Министерства народного просвещения, 1871. №2. С. 184-185.

3. Кан О.Ю. Историография подготовки будущих филологов в университетах Украины во II половине XIX - начале XX века. Докладь Казахской академии образования / редкол. А.К. Кусайынов (глава) и др. Астана, 2018. №5. С. 48-56.

4. Кан О.Ю. Організація філологічної освіти на філософському факультеті Львівського університету імені Яна Казимира у 1850-1917 роках. Педагогічний альманах : збірник наукових праць / редкол. В. В. Кузьменко (голова) та ін. Херсон : КВНЗ «Херсонська академія неперервної освіти», 2017. Вип. 33. С. 280-285.

5. Кан О.Ю. Формы, методы и приемы обучения филологических дисциплин в университетах Украины во II половине XIX - начала XX века. Современные проблемы гуманитарных и социальных наук: материалы международной научно-практической конференции / под общей редакцией А.К. Кусаинова (7 декабря 2018 года, г. Астана). Астана: Евразийский гуманитарный институт, 2018. С. 130-133.

6. Латышев В. Очерк греческих древностей. Пособие для гимназистов старших классов и для начинающих филологов. Издание 2-е перераб.. С.-Пб.: Тип. В. Безобразова и Комп., 1888. 355 с.

7. Левицька Н. Науково-методичне забезпечення вищої гуманітарної освіти Наддніпрянщини: друга половина XIX - початок XX століття. Украӥнознавство. 2012. № 3. С. 171-176.

8. Общий устав Императорских Российских Университетов (18 июня 1863) // Сборник постановлений по Министерству Народного Просвещения. СПб., 1855-1864. T. 3. C.1040-1106. 
9. Общий Устав императорских российских университетов 1884 года. Харьков, $1911.59 \mathrm{c}$.

10. Петько Л.В. Іншомовна освіта у контексті формування нового вчителя в умовах університетської підготовки. Педагогіка вищої та середньої школи: зб.наук.праць ; за ред. З.П.Бакум. Криворізький педагогічний інститут ДВНЗ «Криворізький національний університет». Вип. 39. Кривий Ріг : Друкарня Романа Козлова, 2013. С. 232-237.

11. Петько Л.В. Освітнє середовище університету та іншомовна підготовка студентів // Модернізація освітнього середовища: проблеми та перспективи : Матеріали Четвертої Міжнародної науково-практичної конференції (м. Умань, 11-12 жовтня 2018 р.) / гол. ред. Осадченко І. І. Умань : ВПЦ «Візаві», 2018. 184 с. С. 117-120.

12. Программа по английському языку за 1852-1853 учебный год / Державний архів м. Києва (ДАК). Ф. 16, оп. 465, спр. 96, 53 арк.

13. Программы полукурсового испытания студентов историко-филологического факультета в Императорском Харьковском университете. Харьков: Университетская типография, $1891.38 \mathrm{c}$.

14. Слюсаренко Н. В., Кохановська О. В. Трансформація вищої жіночої освіти в Україні (XIX - початок XXI століття). Вісник Черкаського університету (Серія Педагогічні науки). Випуск 2. 2018. Черкаси: Черкаський національний університет імені Богдана Хмельницького, 2018. С. 124-130.

15. Слюсаренко Н.В. Форми і методи виховної роботи у вищих навчальних закладах. Таврійський вісник освіти. 2009. №3 (27). С. 107-116.

16. Срезневский И. И. Пособие к чтению Гомера. Выпуск І. Етимология Гомеровского диалекта и комментарии на 1-ю песнь Одиссеи. СПб, 1875. 80 с.

17. Таблица распределения учебных предметов и времени преподавания в Императорском Харьковском университете на 1850/51 учебный год. Харьков, 1850. 11с.

18. Флоринский Т. Лекции по славянскому языкознанию. Киев : Ун-т св. Владимира, 1897. 703 с.

19. Finkel L., Starzycski S. Historya uniwersytetu Lwowskiego. Lwyw: Drukarnia E. Winiarza, 1894. 351 p.

20. Norst A. Alma Mater Francisco-Josephina, Festschrift zu deren 25-jährigem Bestande, 1900. $146 \mathrm{p}$. 